\title{
Local and Supra-regional Significance of Romanesque Sculpture and its Place in Art History - the Example of Bas-reliefs from a Church in Inowrocław ${ }^{1}$
}

\author{
Przemysław WASZAK \\ Science [like art] deals with phenomena, not facts ${ }^{2}$ \\ George Kubler's note from Henri Focillon's lectures, Yale, 5 January 1940
}

\begin{abstract}
This paper addresses the issue of Romanesque sculpture and presents it by means of describing the ensemble of masks preserved in the Romanesque, partially reconstructed, church dedicated to the Name of the Blessed Virgin Mary, a symbol of Inowrocław. This text addresses the well-known sculptures analysed from a contemporary research and methodological perspective in respect of the history of medieval art. Artistic analogies, aesthetic sources, and the practice of ornamenting the Houses of God with stone masks have been presented and new interpretations of iconography, form, and meaning have been discussed. Issues concerning artistic geography, style, significance, law of the frame and technique have been considered and compared.
\end{abstract}

Keywords: Middle Ages, Romanesque, cultural heritage, Romanesque sculpture, medieval sculpture, stone sculpture, Inowrocław, Poland, masks, law of the frame

\section{Research subject and scope}

In this paper a concrete example of Romanesque sculptures will serve to discuss the role of medieval

\footnotetext{
The paper is a version - extended and provided with footnotes - of the speech delivered on 7 April 2018 at the Polish academic conference Polska gminna i powiatowa - regiony na przestrzeni driejón [Poland of Municipalities and Districts - Regions throughout History] held at the Faculty of History of the University of Gdańsk. The research into the topic discussed in the text was made possible owing to the scholarship of Polska Misja Historyczna [Polish Historical Mission] in Würzburg, founded by Bayerische Staatskanzlei [Bavarian State Chancellery]; the scholarship of the Herder Institute in Marburg, and a grant obtained from the Faculty of History of the Nicolaus Copernicus University in Toruń, no. 1173-NH. I presented the research results in English on 5 July 2018 at the International Medieval Congress Leeds: The Significance
}

artworks in the memory of generations - a kind of sites of memory, les lieux de mémoire. The topic of bas-reliefs from Inowrocław will be introduced by means of the description, analysis, and comparison 
of these artworks with others that are similar in terms of chronology, typology, function, material or geography and that were sculpted using a parallel technique. Their regional and supra-regional significance will also be indicated.

In the early 12th century, the Cistercian Hugh of Fouilloy defied visual catechesis by writing in an anti-pragmatic, anti-aesthetic, and anti-artistic spirit: "The stone is useful in building, but wherefore sculptures in the stone?", which clearly demonstrates that sculptures or paintings ornamenting Romanesque church walls were not taken for granted. Reservations concerning figural arts were voiced frequently, to mention the famous, moving recommendations of Bernard of Clairvaux contained in Apologia ad Guillelmum Sancti Theoderici Abbatem [Apology to William of St. Thierry].

The considerations contained in this paper will take the reader to northern Poland, to the historical region of Kujawy [Cuiavia], to the town of Inowrocław situated in the lowland of Pojezierze Wielkopolsko-Kujawskie [Greater Poland and Cuiavia Lakes], in Równina Inowrocławska [the Inowrocław Plain]. ${ }^{4}$ The subject of analysis will be Basilica Minor dedicated to the Name of the Blessed Virgin Mary, the most prominent monument of Inowrocław - a spa famous for its brine and graduation towers and a historical town on the Piast Trail. ${ }^{5}$ The church is broadly known not only to medievalists and art historians conducting research into other periods. It riveted scholars' attention particularly in the 19 th century and has attracted it ever since. Dating back to the turn of the 12th and 13th centuries (Fig. 1), this Romanesque church must have been erected extra muros - outside the trade settlement, on a small hill. It underwent two major renovations: at

\footnotetext{
3 TATARKIEWICZ, W.: Medieval aesthetics. Ed.: BARRETT, C., translated by R. M. MONTGOMERY. Hague - Paris Warszawa 1970, p. 174: „Utilis est lapis in structura, sed quid prodest in lapide caelatura?”. Also: DAVY, M.-M.: Symbolikea romańska (XII w.), translated by K. WAKAR. Warszawa 2011, p. 236 (quote from De claustro animae II, 4).

4 KONDRACKI, J.: Geografia regionalna Polski. Warszawa 2001, pp. 137, 145, 146, fig. 22 on p. 125.

5 Stownik geograficzno-krajoznawcsy Polski. Ed.: MILESKA, M. I. Warszawa 1994, p. 212.
}

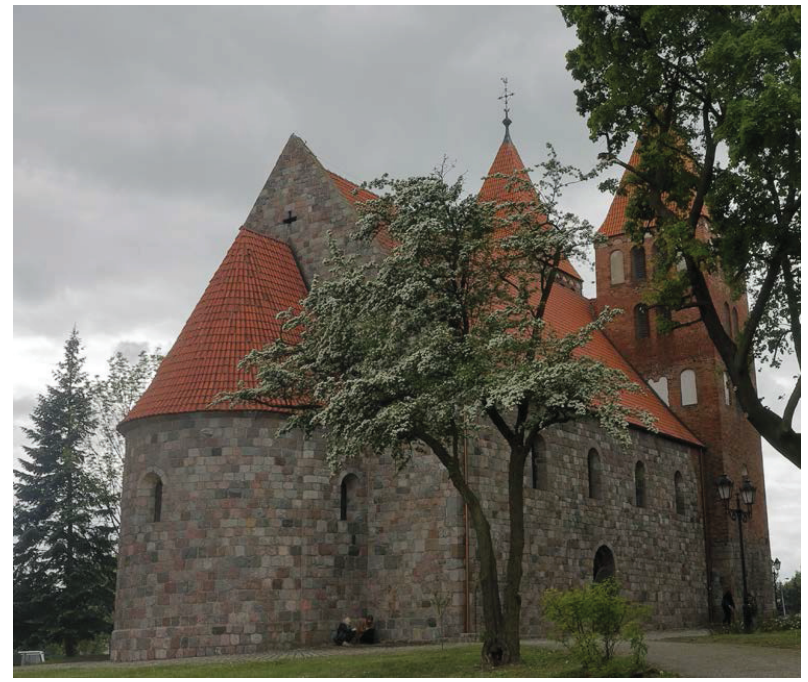

Fig. 1: Inowroctaw, The Church dedicated to the Name of the Blessed Virgin Mary, c. 1200, partially reconstructed, north-eastern view. Photo by author, 2015.

the beginning and in the early second half of the 20th century. The works were conducted in compliance with puristic art conservation doctrines, advocating the restoration of stylistic coherence and comprised of far-fetched restoration-reconstruction, recreation of the Romanesque style in line with the contemporary understanding of the Romanesque style. Before that the very church had been reconstructed in the Gothic and Baroque styles of which barely any traces had been left. ${ }^{6}$

The paper will address the most emblematic element of the church and a feature representing the Romanesque style in Poland - semi-three-dimensional sculptures and engravings made on the surface of ashlars set in the outer face of the northern

${ }^{6}$ FRYCZ, J.: Architektura i sztuka Inowrocławia. In: Drieje Inowroctawia, vol. 2, (Od 1919 r. do końca lat siedemdziesiatych). Ed.: BISKUP, M. Warszawa - Poznań 1982, p. 435; WASZAK, P.: Dzieło sztuki jako ogniskowa pamięci ujęta na tle współczesnej problematyki dziedzictwa kulturowego. Jego rola w kształceniu. Studium przypadku. In: Studia i szkice z. badań nad pamiecia zbiorowa w Polsce w XX $i$ XXI wieku. Eds.: OPIOLA-CEGIELKA, M. - SZCZUTKOWSKA, J. Bydgoszcz 2020, pp. 158-162, 167, figs. 1, 2, 5. 


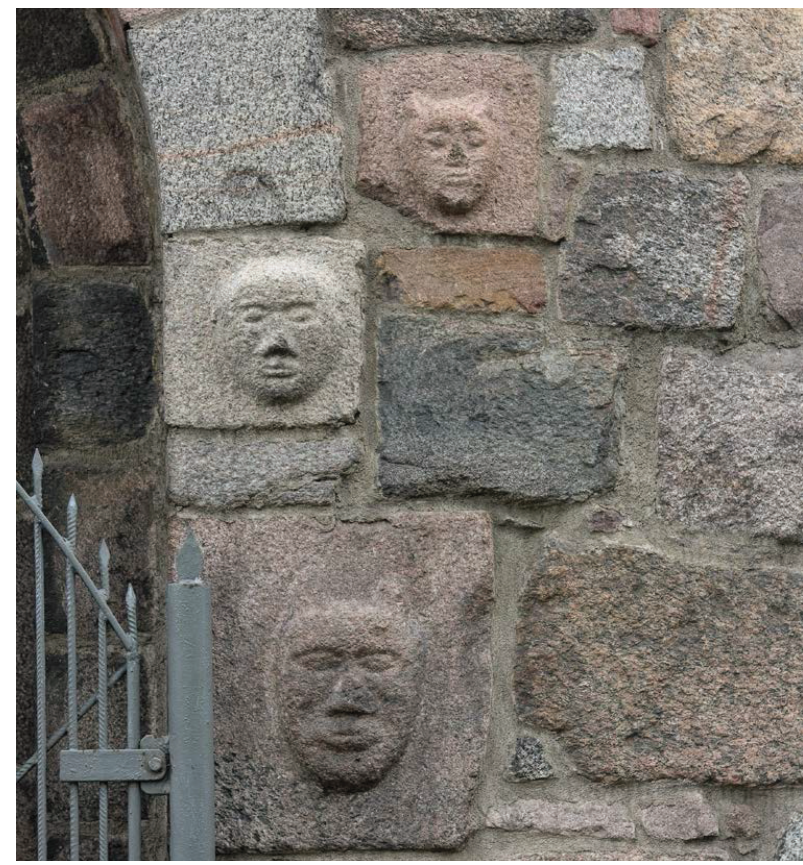

Fig. 2: Inowrockaw, The Church dedicated to the Name of the Blessed Virgin Mary, northern portal, western jamb, masks, granite, c. 1200. Photo by author, 2015.

lateral wall (Figs. 2-7). These examples illustrate the physical integration of sculpture and architecture. The masks are set near the portal referred to as the introitus. ${ }^{7}$ They do not constitute the Paupers' Bible [Biblia pauperum] as - except for the relief in the shape of the cross - they do not teach truths of the faith directly. Thus, they could have an obsistere, apotropaic function meant to avert the powers of evil. ${ }^{8}$ Despite having been set in an outer wall, they do not bear any liturgical significance, either. The idea of setting figural, isolated bas-reliefs, masks, in a wall - especially, fitting them in the portal jambs (Fig. 2)-originated primarily in northern Italy in the Romanesque period. ${ }^{9}$

SAUERLÄNDER, W.: Rz̨eźba średniowiecz̧na, translated by A. PORĘBSKA, Warszawa 2001, pp. 164, 165.

8 Ibidem, p. 164; ŚWIECHOWSKI, Z.: Romanizm. with contribution from ŚWIECHOWSKA, E. Warszawa 2006, (S žtuka polska 1. Ed.: KOWALCZYK, J.), p. 246.

\section{Description of figural bas-reliefs}

The figural reliefs decorating the wall are semi or quite vividly projecting. Most of them depict symmetrical, round or otherwise shaped faces with large, triangular, flat noses and ellipsoidal or almond-shaped eyes that are clearly defined owing to the grooves engraved around them. Similar, relatively deep grooves outline the shape of closed mouths. Such delineation of physiognomic features, particularly the sight, is typical of Romanesque sculpture, which constitutes a "bridge to the unseen". The outlining of facial features differs in particular works that vary in terms of the degree of subtlety, elegance, simplicity, unevenness or irregularity. It is similar with iconography - the representations of demons are characteristic of 12 th-century sculpture and were often carved in capitals. ${ }^{10}$ The masks differ in terms of face contours, the relation to the granite background, and the forms used. The fact that one of the masks is tilted and set outside the centre of the ashlar provides it with certain dynamics and disrupts the optical statics and stability of the bas-relief (Fig. 5). Most physiognomies were depicted individually and carved en face in the centre of the ashlar, looking straight ahead. The faces became more geometrical, were made conventionally simpler by featuring fewer grooves that outlined the physiognomic traits, and had expressive facial features added. The bas-reliefs display symbolic attributes and assume certain anthropomorphic, yet ambiguous, shapes. The handling of the stone is quite rough, and thus slightly schematic. The author did not provide the faces with sharp, angular features or he limited the use of such forms to a considerable extent. The perception of their shapes resembles the reception of flattened spherical surfaces (Fig. 3). Sculpture surface stretches from the base - the point of contact with the background - and projects towards

\footnotetext{
9 Confer: Ibidem, pp. 232, 233; QUIRINI-POPŁAWSKI, R.: Ržeźba przedromańska i romańska w Polsce wobec sz̨tuki wtoskiej. Kraków 2006, p. 60.

${ }^{10}$ WEIGERT, H.: Romanische Plastik in Europa. Eds.: BUSCH, H. - LOHSE, B. Frankfurt am Main 1961, pp. VI, VIII, XXV and figures.
} 
the central part of the bas-relief, thus highlighting the surface within which they are little diversified. Their main mass is characterised by compactness and bulkiness; they handle spherical, rough surfaces, that is a kind of curvatures or curved surfaces. Small elements such as ears, a moustache or a nose were added, as if glued, to their mass. The composition of bas-reliefs on the surface of the granite blocks is distinguished by clarity and vivid - perhaps symbolic - outlining of the representation as well as by compactness, a certain closure. Deprived of religious commentary, the symbols contained in Romanesque bas-reliefs might be difficult to be appropriately interpreted by believers. ${ }^{11}$ Naturally, many medieval religious or moralising artworks functioned as visual catechesis or instruction. This particularly pertains to the Inowrocław bas-reliefs that were exposed in a public place.

The relationship between the architectural background and the bas-relief is reflected in the description of the mask from Inowrocław as an embraced form and the background as an embracing form. ${ }^{12}$ Although the architectural embracing form is of superior importance, the sculptural one bears greater artistic significance owing to the fact that it projects from the background, towers over it, and rivets the viewer's attention. It is absolutely essential that Romanesque sculptors who created works subordinated to architecture complied with "the principle of space as a limit."13 Thus, the significant dimension of the unhandled, almost flat, framing of the masks in question can be considered in the light of amor vacui. Reliefs shape space; they became subjected to their own laws of art. ${ }^{14}$ With the passage of time - just as in the case of other artworks - the form of bas-reliefs becomes more and more autonomous, liberated ${ }^{15}$ probably also from its own original conditions and contexts.

\footnotetext{
${ }^{11}$ DAVY 2011 (see in note 3), p. 104.

${ }^{12}$ Examples of the use of this terminology can be found in: JARZEWICZ, J.: Kościoty romańskie w Polsce. Kraków 2014, p. 15.

${ }^{13}$ FOCILLON, H.: The life of forms in art. Trans. by C. B. HOGAN - G. KUBLER. New York 1996, pp. 79, 125.

${ }^{14}$ Ibidem, pp. 65, 67.
}

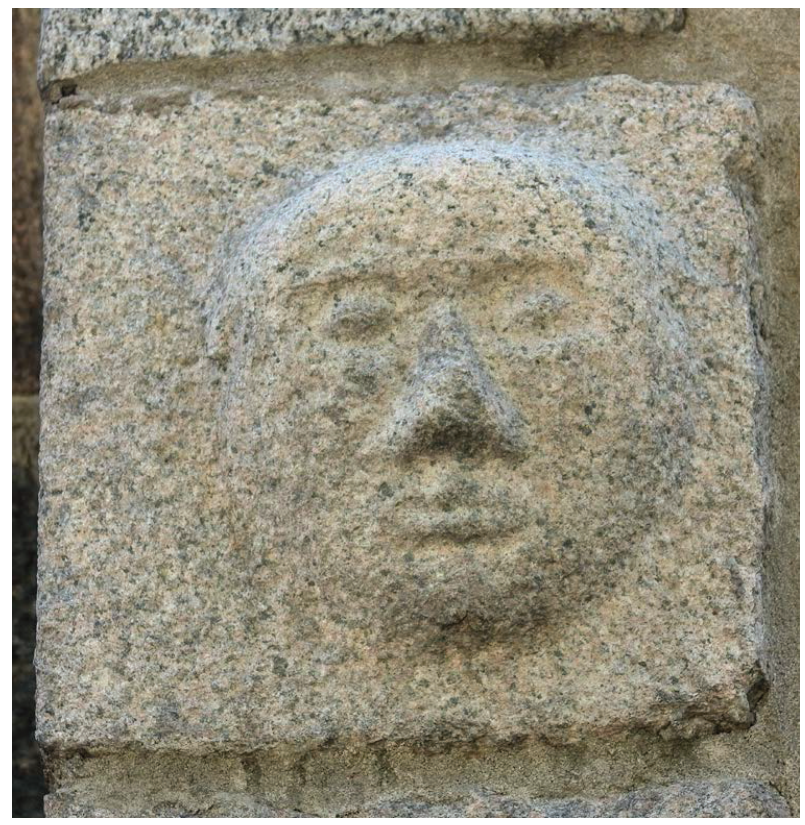

Fig. 3: Inowroctaw, The Church dedicated to the Name of the Blessed Virgin Mary, northern portal, mask with rounded features, c. 1200. Photo by author, 2018.

In Romanesque art "the integration of architecture, sculpture, and ornament formed an inseparable, three-dimensional whole." ${ }^{\prime 16}$ The Inowrocław masks have a more autonomous character than the other ones found in bosses or keystones that are architectural details with ornamental, decorative properties. The term "embracing form" was developed by Hans Sedlmayr in reference to medieval artworks. ${ }^{17}$ It was particularly in the context of architectural and sculptural forms that he found the tension and relationships between the embracing and the embraced forms, e.g. arcades inscribed one into one another or an enclosed space, to be the distinguishing features of Romanesque art. ${ }^{18}$ Furthermore, in the

${ }^{15}$ Ibidem, p. 156.

${ }^{16}$ SEDLMAYR, H.: Europäische Romanik im Lichte ihrer kritischen Formen. In: Idem: Epochen und Werke: gesammelte Schriften zur Kunstgeschichte, vol. 3. München 1982, p. 68.

${ }^{17}$ SEDLMAYR, H.: Das erste mittelalterliche Architektursystem. In: Idem: Epochen und Werke: gesammelte Schriften zur Kunstgeschichte, vol. I. München 1977, pp. 81-95.

${ }^{18}$ SEDLMAYR 1982 (see in note 16), pp. 58, 60, fig. 21 on p. 57. 


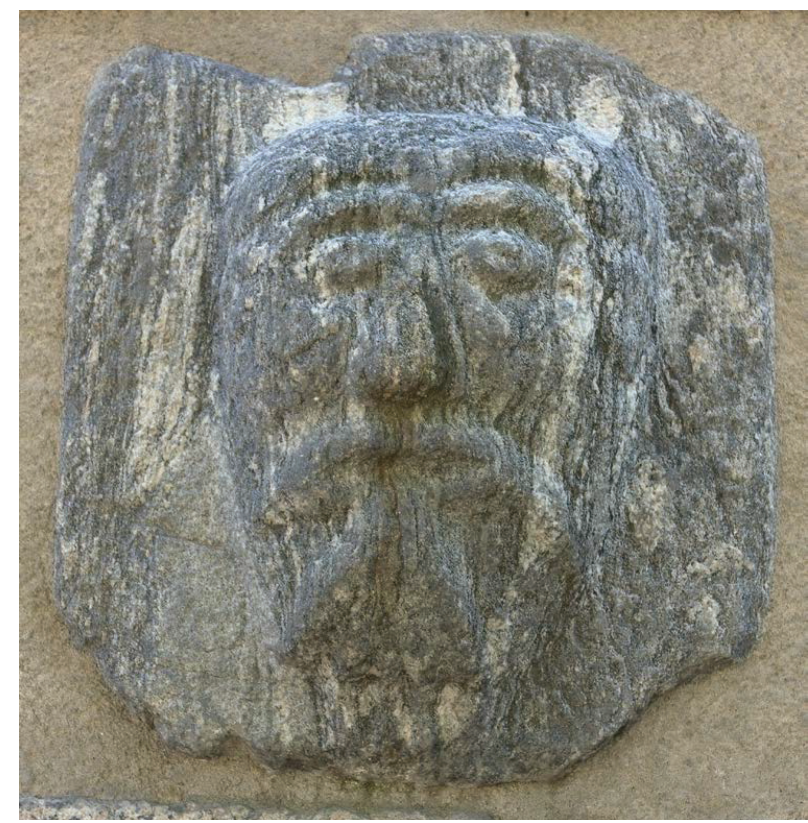

Fig. 4: Inowrockaw, The Church dedicated to the Name of the Blessed Virgin Mary, northern wall, bearded mask temporarily kept at the Kórnik Library of the Polish Academy of Sciences, granite, c. 1200. Photo by author, 2018.

accessible introduction to Romanesque art, Françoise Leriche-Andrieu points out such features of Romanesque sculpture as: "architectonicity, hieraticity, symbolicity, ornamentality, decorativeness" and the handling of geometric shapes. ${ }^{19}$ Modified and customised, the above-mentioned basic determinants can be referred to the Inowrocław reliefs.

What is accessible and - at the same time - most interesting for the viewer is just one, the outer, side of the granite block, sculpted in a roughly rectangular form. Used as carving material, erratic stones were probably skilfully handled on only one, face side as depicted in the photographs of the ashlars extracted from the wall and displayed as a part of a museum collection. ${ }^{20}$ The material says much about the work itself. Most probably, it indicates that the bas-reliefs

\footnotetext{
${ }^{19}$ LERICHE-ANDRIEU, F.: Einführung in die romanische Kunst. Trans. by K. KOLB. Würzburg 1985, pp. 90-93, 110.

${ }^{20}$ BIAŁŁOWICZ-KRYGIEROWA, Z.: Romańskie ciosy z płaskorzeźbionymi maskami z kościoła Panny Marii w Inowrocławiu. Przyczynek do historii zbiorów kórnickich
}

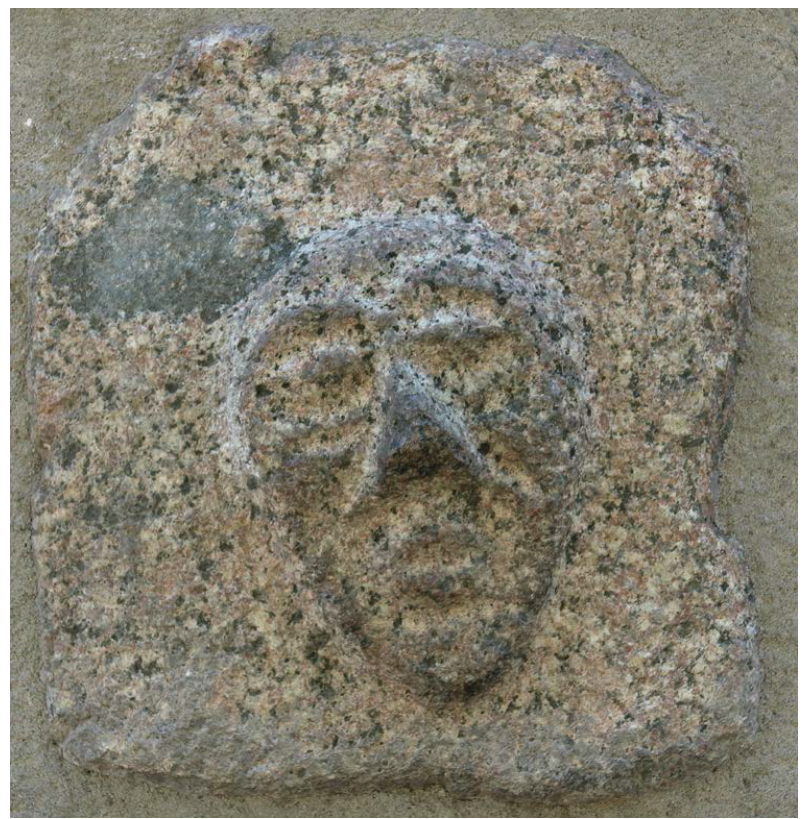

Fig. 5: Inowroctaw, The Church dedicated to the Name of the Blessed Virgin Mary, northern wall, lenticular, tilted mask temporarily kept at the Kornik Library of the Polish Academy of Sciences, granite, c. 1200. Photo by author, 2018.

were made locally from post-glacial granites - erratic boulders available in the lowland, in Niż Polski [the Polish Plain], the very same ones which were used in the form of granite setts to build a significant part of the stone and brick church in Inowrocław and other churches in the area. The majority of the walls of the nave as well as the lower parts of the two-towered western front of the building were made of erratic granite. The question of the origin of the material is less unambiguous in the case of similarly dated and geographically close Romanesque sculptures from Strzelno in the Kujawy region. According to petrographic analyses, the two types of sandstone from which they were created might come from more or less distant quarries located in the Sudetes and near Konin. ${ }^{21}$ The use of sandstone in Strzelno

Tytusa Działyńskiego. In: Studia Murealne, 12, 1977, fig. 3, endnote 1.

${ }^{21}$ SOĆKO, A.: Romańskie detale kamieniarskie kompleksu klasztornego w Strzelnie w Muzeum Narodowym w Poznaniu. Uwagi na marginesie prac nad katalogiem zbiorów Ga- 
facilitated the sculpting of soft, fine, smooth, and nuanced forms. Although the Inowrocław sculptures have stayed in place since the turn of the 12th and 13th centuries, they have not stayed strictly in situ. Their placement on the wall might change due to the gradual deterioration of the church and due to the fact that the temple had been a ruin since the fire in 1834. For over one and a half centuries, from 1856 to 2011 , two ashlars with particularly original masks belonged to the collection of the Kórnik Library of the Polish Academy of Sciences (Figs. 4, 5). ${ }^{22}$ The said ashlars with engravings and bas-reliefs can be considered as commonly known in Polish art history, history, ethnography, and archaeology. They have been vastly present and illustrated in tourist guides as well as in regional studies. ${ }^{23}$ They have also been interpreted in multiple ways. ${ }^{24}$ For example, Józef Aleksandrowicz emphasised that the masks from Inowrocław were "fit for the cover." 25

The Inowrocław masks are examples of Romanesque art. Many masks demonstrate the diversity of medieval art, also in respect of artistic geography, even that covering a short distance, and a slightly different time of origin, encompassing merely several generations. The dissemination of knowledge about the masks from Inowrocław in Poland can be compared to the awareness of the existence of another

lerii Sztuki Średniowiecznej. In: Visibilia et invisibilia w sztuce średniowiecza: ksiega poświecona pamieci profesor Kingi Szczepkowskiej-Naliwajek. Eds.: BADACH, A. -JANISZEWSKA, M. TARKOWSKA, M. Warszawa 2009, pp. 35-37, 40, 42, fig. 6.

22 BIAŁLOWICZ-KRYGIEROWA 1977 (see in note 20), pp. 11-22; DANIELEWSKI, M.: Reliefy z murów kościoła Panny Marii w Inowrocławiu. In: Roczniki Historyczne, 77, 2011, p. 11.

${ }^{23}$ Extensive expert literature and the ensemble of representations from Inowrocław are discussed by Ibidem, pp. 7-32.

${ }^{24}$ E.g.: SIKORSKI, C.: Reliefy z murów kościoła Imienia Najświętszej Marii Panny w Inowrocławiu. In: Ziemia Kujawska, 11, 1995, pp. 17-34; HEWNER, K.: Kim był twórca romańskich rzeźb na murach kościoła Imienia Najświętszej Marii Panny w Inowrocławiu? In: Ziemia Kujawska, 13, 1998, pp. 151-157; SROKA, Z.: Zagrożenia i lęki średniowiecznych inowrocławian (problematyka płaskorzeźb i rytów na kościele pod wezwaniem Imienia Najświętszej Marii Panny w Inowrocławiu). In: Materialy do dziejów kultury i satuki Bydgoszcsy i regionu, 6, 2001, pp. 106-122; HEWNER, K.: Funkcja rzeźb i rytów na murach romańskiego kościoła pw. Imienia exceptional, extensive, and typologically-similar set of French sculptures known in Western art. It comprises of different - almost three-dimensional - heads sculpted deeply and meticulously with virtuosic rendering of vivid facial expressions, a large dose of imagination in reflecting dynamic poses, and attention to even minute detail. The sculptures are set and function as corbels in the upper parts of the Cathedral of Notre-Dame in Reims, where French kings were crowned. More precisely, they were set in the choir and the transept windows - the clerestory. Referred to as the "Reims masks", they still attract the attention of visitors and scholars. ${ }^{26}$ They originated a little later than the Inowrockaw masks - at the end of the first three decades of the $13^{\text {th }}$ century, that is the years 1230-1233 - and display typically Gothic features and a more advanced systematic age. They were created in the centre of artistic transformations and were imitated, for example in Canterbury. ${ }^{27}$ These - mainly anthropomorphic - representations can be compared to popular Gothic gargoyles in terms of their flamboyance as well as a free approach to formality and iconography. Dating back to about a century later (the years 1330-1340), a similar example of an anthropomorphic Gothic mask crowned with foliage can be seen on the corbel in a small refectory in the Middle Castle in Malbork. ${ }^{28}$ Many

NMP w Inowrocławiu: głos w dyskusji. In: Ziemia Kujawska, 17, 2004, pp. 213-217.

${ }^{25}$ ALEKSANDROWICZ, J.: Inowrocław i okolice: rabytki, uqdrowisko, mybitni ludzie, ciekawe okolice. Inowrocław 1982, p. 156, 157, fig. on p. 155.

${ }^{26}$ NØDSETH, I. L.: Reframing the margins: Marginalised sculpture on Gothic cathedrals: the human face as an aspect of the marginal in the cathedrals of Reims and Trondheim. In: Collegium Medievale, 26, 2013, pp. 14-19, plate 1 on p. 24; SCHMENGLER, D.: Die Masken von Reims: zur Genese negativer Ausdrucksformen zwischen Tradition und Innovation. Berlin 2016, passim.

${ }^{27}$ WILLIAMSON, P.: Gothic sculpture, 1140-1300. New Haven London [presumably 1998], p. 65, figs. 97, 98; BINSKI, P.: Gothic sculpture. New Haven - London 2019, pp. 118-120, figs. 42, 56, 57; SAUERLÄNDER, W.: Das Jabrbundert der grossen Kathedralen: 1140-1260, (Gotik 1). München 1990, pp. 142, 146, 149, figs. 143, 146.

28 JURKOWLANIEC, T.: Gotycka ræę̧́ba architektonična w Prusach. Wrocław 1989, pp. 50, 182, cat. no. 96.B.III.14, fig. 227. 
more masks set in keystones, capitals, and consoles can be found in the area of the former State of the Teutonic Order in Prussia. ${ }^{29}$ The Reims masks were also created and interpreted in the light of medieval theology, probably in order to illustrate vices. ${ }^{30}$ Their distinctive physiognomic features are realistic, strongly individualistic, sometimes extraordinarily vivid and sometimes deformed, but still reflected artistically with fertile imagination.

The Inowrocław masks are characterised by a diversified, natural colour of granite, occurring in several shades changing even within one block. In line with the etymology of the word 'granite' (in Latin granum means grain), the granular structure of the stone and even the coarse, not ideally smooth, but rough, texture become visible in the sculptures made of this rock. The projecting reliefs discussed herein are clearly distinguished and heterogeneous within one coherent type - a sculpture depicting physiognomy. The bas-reliefs were made of durable material and permanently united with architecture. They are an architectonic, monumental kind of sculpture. They were compositionally and optically monumentalised. They are infused with an intrinsic, focused force exerting visual impact and with objectively elusive mystery, rawness, extraordinariness, and uniqueness, evoking at least curiosity as confirmed by numerous publications and divergent interpretations. In this context, it is worth mentioning a literary work that originated in the second half of Young Poland, a period of major importance for literature. In "Starożytny kościół" ["The Ancient Church"], a piece written in poetic prose and contained in the collection titled O bohaterskim konin $i$ walacym sie domu [On a Heroic Horse and a Dilapidated House] from the year 1905/1906,31 Jan Kasprowicz expressed not only the contemporary views on the identification and polytheistic origin of the sculptures, propounded

\footnotetext{
${ }^{29}$ Ibidem, passim.

${ }^{30}$ BÜCHSEL, M.: Gothic Sculpture from 1150 to 1250. In: A companion to medieval art: Romanesque and Gothic in Northern Europe. Ed.: RUDOLPH, C. Malden, Mass. 2006, p. 411.

${ }^{31}$ KASPROWICZ, J.: Utwory literackie, vol. 4, Ed.: LOTH, R., Kraków 1984, pp. 445, 446, 829.

${ }^{32}$ Ibidem, p. 445.
}

even later, in postwar works. First of all, knowing the sculptures from personal experience, he expressed in words his own literary sensitivity to the unusual form and iconography of the Inowrocław bas-reliefs. As in a lens, he focused on the most distinctive relief features. He was encouraged to engage in dialogue with the sculptures as witnesses of past times and exhibitors of incomprehensible, forgotten ideas. A relevant fragment of the said piece reads: "Coarsely sculpted heads of deities - allegedly from a pagan temple - looking at others with torpor, engaged with me in a conversation in which my inept, lonely song reverberated." ${ }^{32}$

\section{Masks and the law of the frame}

It is typical of Romanesque sculpture to comply with the law of the frame formulated by methodologist Henri Focillon whose sensitivity to artworks is reflected in, among others, the considerations found in the book The Life of Forms. ${ }^{33}$ In line with the law of the form, sculptures, including figural ones, adapt their shapes and features to architectural forms: a capital or a frieze, while figures assume unnatural poses and are subject to ornamentation. ${ }^{34}$

In his synthesis of Romanesque sculpture, Millard Fillmore Hearn polemicises with the law of the frame and Focillon's research. ${ }^{35}$ While appreciating his achievements, Hearn states that Focillon's methodological essay "cast a spell upon his readers." ${ }^{36}$ Hearn lists the features Focillon considered as essential for the law of the frame - the core law governing Romanesque sculpture, that is: close relation of sculpture with architecture, distortion, unnatural and scrupulously accurate adaptation of sculpture to architectural structures and architectural forms contours, limitation by the material and its shape as well as the near adherence of congested compositions to the

${ }^{33}$ FOCILLON 1996 (see in note 13), passim.

${ }^{34}$ PRZYBYSZEWSKI, B.: Romanskie kościoły pielgraymkowe. Kraków 1979, p. 179.

${ }^{35}$ HEARN, M. F.: Romanesque sculpture: the revival of monumental stone sculpture in the eleventh and twelfth centuries. New York 1985, passim.

${ }^{36}$ Ibidem, p. 14. 


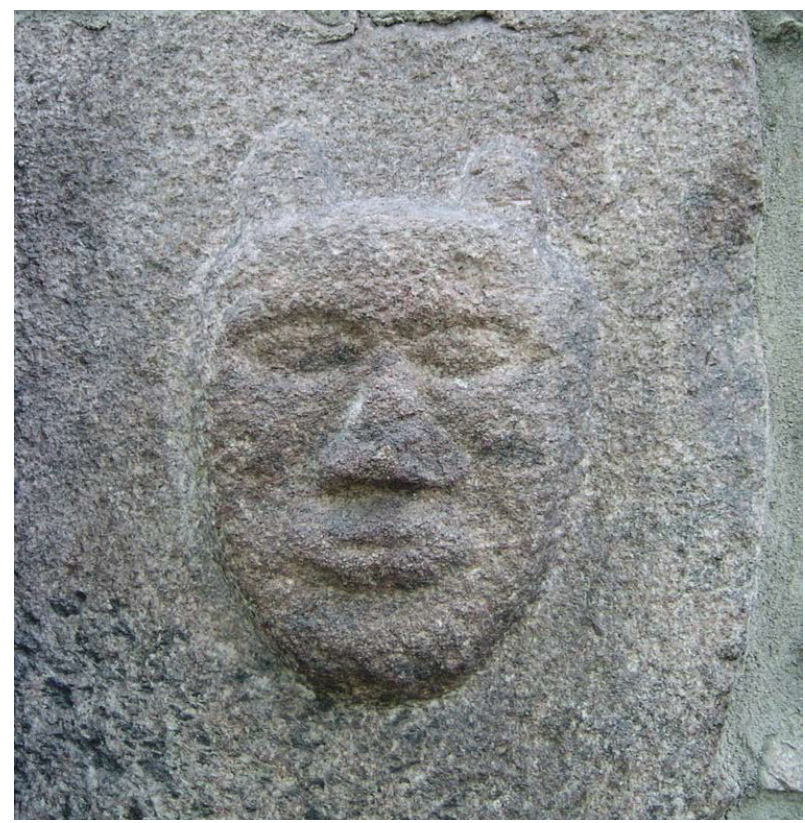

Fig. 6: Inowroclaw, The Church dedicated to the Name of the Blessed Virgin Mary, northern wall, mask, with pointed ears, granite, c. 1200. Photo by author, 2007.

principle of the fear of empty spaces (horror vacui)..$^{37}$ The law of the frame (known as rigueur du cadre and Gesetz des Rahmens in French and German, respectively) was further developed by Focillon's student, a Lithuanian art historian Jurgis Baltrušaitis who noticed that the representations in small and large scale are based on abstract, geometric principles. ${ }^{38}$ It is possible to recreate Baltrušaitis's thought by referring to Meyer Schapiro's polemical review. ${ }^{39}$ Following Hearn, one can accept criticism or - on the contrary - adopt Focillon's formalistic thinking as Nikolaj Worobiow did. ${ }^{40}$ Nevertheless, it is essential that - referring to formal and compositional issues the law of the frame is a major point of reference for the Inowrocław bas-reliefs. Questioning the law of the frame does not undermine the value of this

\footnotetext{
${ }^{37}$ Ibidem, pp. 14-15, 42, 49, 55-56, 130-132, 138, 142, 156 , 161, 163, 170, 191.

${ }^{38}$ Ibidem, p. 5.

${ }^{39}$ SCHAPIRO, M.: Über den Schematismus in der romanischen Kunst, Jurgis Baltruśaitis, La stylistique ornamentale dans la Sculpture
}

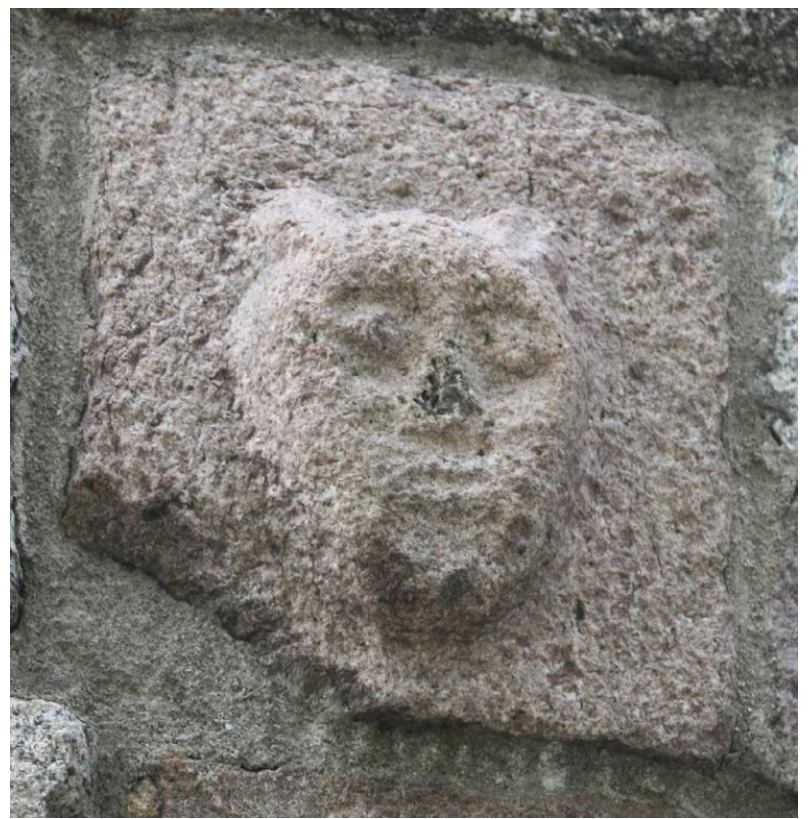

Fig. 7: Inowroctaw, The Church dedicated to the Name of the Blessed Virgin Mary, northern wall, smaller mask, with exaggerated ears, granite, c. 1200. Photo by author, 2019.

formal notion of Romanesque sculpture that strove to classify and define the stylistic system of the stone sculpture of the 11 th and 12 th centuries.

As a matter of fact, the visitor will not notice any adherence to the law of the frame in Inowrocław. Despite being indisputably embedded in architecture and bearing architectural features, the masks project freely from the stone. What distinguishes these bas-reliefs is only the free, empty, almost flat surface left around them and enriched with the texture and diverse colours of granite; to a certain extent, it is a lack of form and any floral or geometric ornamentation of the margin or passe-partout. Owing to this framing space, the bas-reliefs freely project from the surface of the ashlar and, contrary to the law of the frame, become meaningful and indepen-

Romane, Pairs, Leroux 1931. In: Kritische Berichte zur kunstgeschichtlichen Literatur: (1927-1937); 6 T. in e. Bd. Eds.: ANTAL, F. - FÜRST, B. Hildesheim - New York 1972, pp. 1-21.

${ }^{40}$ WOROBIOW, N.: Zur Neubegründung des Formalismus, Henri Focillon, Vie des formes. Paris, E. Leroux 1934. In: ANTAL - FÜRST 1972 (see in note 39), pp. 40-65. 
dent. Consequently, the framing space aesthetically subordinates itself to the bas-reliefs and provides them with technical background, a kind of reinforcement. By contrast, the sculptures from the parish church dedicated to Saints Peter and Paul in Stare Miasto near Konin, ${ }^{41}$ dated at a similar time, that is the early 13th century, and also depicting human heads and an owl's head comply with the law of the frame and adapt themselves to the rectangular corner of the portal frame and the shape of the extended mullions that they crown. Architectural features, planarity, and relief are the properties of monumental Romanesque sculpture that depends on architecture with which it constitutes a whole. In particular, they are typical of high-reliefs, ${ }^{42}$ such as the examples discussed herein.

Formalist approaches to the analysis of Romanesque sculpture date back to 1931. They focused on determining the principles governing the visual structure of artworks. The concept and theory of architectural frame defining Romanesque sculpture was developed by the aforementioned Baltrušaitis. ${ }^{43}$ This author illustrated the transformations of the form in an extraordinary manner and provided the rich and colourful descriptions of sculptures with certain dynamism and organicity. In his narration, he came close to the discussion pertaining to the interpenetrating and interfering artistic phenomena presented with the use of biological and linguistic metaphors. The reader will find similar deliberations in the books of his teacher, Focillon, who appreciated the work of the Lithuanian art historian. ${ }^{44}$ Baltrušaitis mentions the inseparable relation of architecture and Romanesque sculpture by figuratively saying that "the architect guided the sculptor's chisel." ${ }^{45}$ In his opin-

\footnotetext{
${ }^{41}$ JARZEWICZ 2014 (see in note 12), p. 91, figs. on pp. 92-94.

${ }^{42}$ SAUERLÄNDER 2001 (see in note 7), pp. 150-152, 154.

${ }^{43}$ BALTRUŠAITIS, J.: Ornamental stylistic in Romanesque sculpture (1931). In: Art bistory: an anthology of modern criticism. Ed.: SYPHER, W. New York 1963, pp. 117-131.

${ }^{44}$ FOCILLON 1996 (see in note 13), p. 48.

${ }^{45}$ BALTRUŠAITIS 1963 (see in note 43), p. 128.

${ }^{46}$ Ibidem, p. 130, 131.
}

ion, stone sculptural representations originate at the intersection of figurality and abstraction, the tension between the two trends that become apparent in an artwork. ${ }^{46}$ Reflecting on $11^{\text {th }}$-century Romanesque figural sculpture, Focillon notices that it became subjected to ornamentation and dependent on architectural forms, the wall. ${ }^{47}$ While discussing the laws that govern art, he speaks of "careful respect for the limits of the frame, especially in architecture." 48

\section{Material, formal, and meaning-related contexts}

The juxtaposition of refined granite reliefs with the oval forms of sculptures made in soft sandstone, both of which originated at the same time, reveals marked differences and obvious similarities due to the identical stylistic period in which they were created. Granite is difficult to sculpt and requires skilled handling, as a material it is both hard and brittle. ${ }^{49}$ Certain features of granite have considerable significance in the context of the reliefs discussed in this article. Bas-reliefs that are encompassed in the background - just as the ones from Inowrocław - testify to a more frequent use of this igneous rock. On the other hand, it should be mentioned that this granular rock was inadequate to carve delicate details, that its natural colourful diversity was not necessarily a desirable feature, and that it was difficult to handle with the then low-tech tools. ${ }^{50}$ Still, one cannot overlook the benefits of taking advantage of the colourfulness of granite in sculpture. ${ }^{51}$ Before the relatively small bas-reliefs from Inowrocław were created, large, partially sculpted, and conventionally handled granite blocks could be found in the vicinity of the

\footnotetext{
${ }^{47}$ FOCILLON 1996 (see in note 13), p. 53.

${ }^{48}$ Ibidem, p. 58.

${ }^{49}$ BŁAŻEJEWSKA, A.: Kamienna rzeźba figuralna z czasów przedkrzyżackich w Prusach: stan, możliwości i perspektywy badań. In: Sqtuka Prus XIII-XVIII wieku. Ed.: BOJARSKA, A. Toruń 1994, p. 77.

${ }^{50}$ SYLWESTRZAK, H. - KACHNIC, J.: Kamienne tworayno sz̨tuki. Toruń 2010, pp. 132, 135, 136.

${ }^{51}$ FUGA, A.: Techniki i materiaty, translated by K. A. CHMIELEWSKA. Warszawa 2008, p. 153.
} 
town. ${ }^{52}$ In this context, one should mention - first and foremost - early medieval Prussian statues: stone babas (in German referred to as Bildstein). Although they are classified as pre-Christian art, Anna Błażejewska considers them to have been made as late as during the Christianization of Prussia. The form of the Prussian statues could result from the fact that their makers could be acquainted with the Christian sculpture of considerable size. It is essential that Prussian sculptors consciously chose granite as the sculpting material. ${ }^{53}$ Although it is easy to understand contemporary difficulties of sculpting in granite, it may be acknowledged that the raw handling and simplified forms could be intentional as in the case of artworks resembling the "native", pre-Christian statues created in the neighbouring Prussian lands. ${ }^{54}$ It is worth mentioning that the Prussian stone babas might be a point of reference for the technique and form of the Inowrocław bas-reliefs, including the limitations and opportunities imposed by the sculpting material chosen in both cases by the creator and the client-programmer-author of the concept who were aware of the visual and semantic features of the material. Carved in sandstone, the figures from Wrocław as well as the statues of lions sculpted in granite - popular igneous rock - and deriving from Silesia, for example from Sobótka and Górka, also date to the Romanesque period, to the 12th and 13th centuries. ${ }^{55}$ The latter were carved in considerable scale, but at the same time simplified due to damage, distortion, and the extent of completion. The dating of the stone lions was a subject of dispute

\footnotetext{
${ }^{52}$ Similarity to stone babas was suggested by REINFUSS, R.:
} Ludowa rzę́ba kamienna w Polsce. Wrocław 1989, p. 16.

${ }^{53}$ BŁAŻEJEWSKA, A.: Północny rodowód artystyczny wczesnośredniowiecznych kamiennych figur pruskich. In: Pruskie baby kamienne: fenomen kulturowy cay europejska codzienność?: praca zbiorowa. Eds.: LAPO, J. M. - BIAŁUNSKI, G. Olsztyn 2007, pp. 65-79.

${ }^{54}$ On pre-Christian sculpture see: eadem, 'Native' Figural Art of the Southern Coast of the Baltic Sea at the time of Christianization. In: The Middle Ages, Narratives of Art. Ed.: WENTA, J. - in collaboration with ORENDUFF, C. - KOPCZYŃSKA, M. Toruń 2019, pp. 46, 50, 56, footnote 38.

${ }^{55}$ QUIRINI-POPŁAWSKI 2006 (see in note 9), pp. 119-124, 130-132, figs. 56-58, 60-63. in literature - it was claimed they were made from pre-Christian times to post-medieval ones. ${ }^{56}$

Janina Rosen-Przeworska classified the Inowrocław bas-reliefs as Celtic "heads of the dead". ${ }^{57}$ She represents the stance of a scholar using a different questionnaire and methodology, which results in placing the intriguing Inowrocław monuments on another grid of historical, artistic, and cultural references. By way of analogy, she mentioned stone bas-reliefs from Gaul and Great Britain, two of which were presented slightly differently as full and semi-full figures and depicted Celtic gods. She also discussed regional Celtic contexts. ${ }^{58}$ Some of the early medieval, monumental Irish high crosses that originated and evolved from the $7^{\text {th }}$ until the late $12^{\text {th }}$ century and that served apotropaic functions were made of granite. ${ }^{59}$ Thus, they were created parallel to continental Romanesque sculpture. In my opinion, although distant in terms of space, these Celtic monuments are comparable to the continental ones with regard to a similar, technically-advanced approach to the handling of hard matter, resulting from the specificity of the sculpting material and determining similar formal features of shallowly, yet three-dimensionally, carved granite blocks. Jacek Woźny studied the Inowrocław reliefs against the broad background of European, pre-Christian archaeological monuments, beliefs, and cultural diffusion. ${ }^{60}$

The masks analysed by Herbert Schade are an example, and also a fruit, of the multifaceted, ambiguous culture of the early Middle Ages. They were created as a resultant of many cultural manifestations

${ }^{56}$ Ibidem, pp. 121, 122, 143, footnote 624.

${ }^{57}$ ROSEN-PRZEWORSKA, J.: Przeżytki celtyckie i celto-scytyjskie na obszarze Polski. In: Archeologia Polski, 8, 1963, booklet 1, pp. 104-111, 124.

${ }^{58}$ ROSEN-PRZEWORSKA, J.: Ikonografia wschodnioceltycka. Wrocław 1976, pp. 234, 235, figs. 135, 136.

${ }^{59}$ KLIŚ, Z.: Krzyże iryjskie. In: Folia Historica Cracoviensia, 8, 2002, pp. 279-281, footnotes 2, 4.

${ }^{60}$ WOŹNY, J: Kamienie kultowe jako relikty archaicznych i pogańskich wierzeń religijnych (na kanwie reliefów z kościoła pw. Imienia NMP w Inowrocławiu). In: $Z$ driejów Kujaw i Pałuk. Studia dedykowane pamieci dr. Czestawa Sikorskiego. Eds.: KOZLOWSKI, J. - WOŹNIAK, M. Inowrocław 2005, pp. 32-42. 
and can be perceived through Celtic contexts. Stone masks are often considered to be demonic; yet, they also symbolise souls in purgatory. ${ }^{61}$ The representations that today are thought to depict the world of evil, the world of infernal powers, monstrous or aggressive and full of violence, were not necessarily perceived as such in the Romanesque period. On the contrary, the artworks of the time might have a spiritual dimension and the Romanesque audience treated them as carriers of a spiritual message. Back then, portal sculpture was distinguished by its didactic rather than purely decorative aspect. Poor handling, worse aesthetic values, exaggerated, simplified or anxiety-arousing features of the carved creature and the sculptor's untrained chisel do not have to mean that the opposite of good - demonic forces - were depicted; they do not diminish the mnemonic values of the work or the significance of visual instruction for illiterate worshippers meant to make them understand certain, even abstract, symbolic content, either. ${ }^{62}$ It should be borne in mind that neither Romanesque sculpture, nor medieval literature that described nature was "meant to reproduce reality." 63 Featured in several Inowrocław masks, the pointed, exaggerated ears can be interpreted not only as a demonic attribute; similar exaggerated, pointed ears can rarely be found in other examples of Romanesque sculpture and might signify opening to a spiritual message of wisdom. ${ }^{64}$ By the same token, Gothic art features crucifixes "listening to the pleas of the faithful", distinguished by their size and the orientation of auricles. In his recent essay Hans Belting testifies to the interest in the issue of masks in art; however, he focuses on non-medieval examples and omits the subject of Romanesque masks. ${ }^{65}$ Never-

${ }^{61}$ SCHADE, H.: Dämonen und Monstren: Gestaltungen des Bösen in der Kunst des frühen Mittelalters. Regensburg 1962, pp. 56-61.

${ }^{62}$ WOOD, R.: Paradise: the world of Romanesque sculpture. York 2017, pp. 3, 23, 24, 58, 65, 87, 92-102, 113, 129-135, 137, 141, 143-145, 157-166, 181, 182.

${ }^{63}$ CURTIUS, E. R.: Literatura europejska $i$ tacińskie średniowiecze. Trans. by and ed. A. BOROWSKI. Kraków 2005, p. 191.

${ }^{64}$ Confer: WOOD 2017 (see in note 62), pp. 165, 166.

${ }^{65}$ BELTING, H.: Faces: historia twary, translated by T. ZATORSKI, Gdańsk 2015. theless, it is worth mentioning that the "Middle Ages are full of faces."

Pomeranian monuments of prehistoric art that originated in the late or final stage of the development of tribal, pre-state societies - that is, before or during Christianisation - nowadays function as devoid of the original context. ${ }^{67}$ Apart from the impossibility of reconstructing many issues related to the original set of references, the context of the place, architecture, and placement in the northern side wall of the sacred building remained tangible in the case of the bas-reliefs from Inowrocław.

Prussia - not yet Christianised, late polytheistic, and late tribal at the time considered herein - was a separate area, also artistically, as exemplified by early Prussian sculpture. ${ }^{68}$ Particularly many sculptures created before the final Christianisation phase come from the areas on the southern coast of the Baltic Sea that were subject to Scandinavian artistic influence. ${ }^{69}$ This leads to the conclusion that an early - early medieval or, according to Western categories, Romanesque and pre-Romanesque, pre-Hanseatic - artistic and cultural community of the Baltic Sea coast was established and that it developed artwork-oriented relations.

At a considerable distance from Inowrockaw, there is a place where a stone baba from Poganowo, made of a kind of granitoid (more specifically, tonalite), was found. The site of the Prussian polytheistic cult must have been abandoned before the 12th century, and a number of archaeological ceramic relics date back to the 10th or 11th century. Owing to archaeological discoveries, it became possible to reconstruct some of the contexts of this economically sculptured figure. ${ }^{70}$ With the use of such dating, some mo-

${ }^{66}$ CHRZANOWSKI, T.: Sztuka w Polsce, vol. 1, Od Piastów do Jagiellonów. Warszawa 2008, p. 209. The author quotes a French scholar's opinion.

${ }^{67}$ BŁAŻEJEWSKA, A.: Sztuka „rodzima” na ziemiach polskich w okresie chrystianizacji: próba charakterystyki. In: Ethos: kwartalnik Instytutu Jana Pawta II KUL, 29, 2016, No. 3, p. 43.

${ }^{68}$ Ibidem, pp. 41, 42.

${ }^{69}$ Ibidem, pp. 44, 411.

${ }^{70}$ WYCZÓŁKOWSKI, M.: „Baba” kamienna z Poganowa. Wczesnośredniowieczne miejsce kultu Prusów. In: Batto- 
numental Old Prussian sculptures could have been created prior to - or possibly at a similar time as - the Romanesque ones known from Inowrocław in the Kujawy region. Thus, there co-existed transborder, concurrently developed, and to a certain extent comparable approaches to the sculptural, figural handling of granite erratic stone. Christian art of the Romanesque period also drew on polytheistic Greek and Roman antiquity ${ }^{71}$ Consequently, an exchange with the output of other artistic circles might take place.

The material from which the artwork was made is extremely important. ${ }^{72}$ Paraphrasing and developing Focillon's thought, one should notice a far-fetched difference pertaining to the perception of the significance of the material used by the artist, the ashlar placed in the wall of the sacred building. It was artistically handled and exposes the figural representation, thus clearly surpassing common, granite, irregular, field erratic boulders, granite setts or material coming directly from a quarry. ${ }^{73}$

Within the philosophical notion of tabula rasaa blank slate, one can distinguish its artistic variant a definition of a person who is unaware of the timeless, transnational, cultural, civilisational, and apolitical value of artworks. This can be illustrated by the account of Czesław Sikorski, a historian-regionalist who focused his activity mainly on Inowrocław, in which he reported on the chipping of bas-reliefs, which was typical of his time. ${ }^{74}$ History knows a number of cases when publicly displayed artworks were not plundered, but damaged, for example at the time of the iconoclastic movements in Byzantium, the evangelical movements, and the French Revolution. In these cases, ideologically-motivated acts of violence against art occurred as a consequence of associating sculpture with short-term politics and misunderstanding the pure artistic and aesthetic value of the works. For instance, one can recall

wie i ich sasiedzi: Marian Kaçyńnski in memoriam. Eds.: BITNER-WRÓBLEWSKA, A. - IWANOWSKA, G. Warszawa 2009, pp. 606, 618-620, 631, fig. 14 on p. 619.

${ }^{71}$ LERICHE-ANDRIEU 1985 (see in note 19), pp. 102, 103.

${ }^{72}$ FOCILLON 1996 (see in note 13), p. 102.

${ }^{73}$ On marble, clay, and gold as materials for artworks see: Ibidem, pp. 97, 169. the beheading of the gallery of biblical kings from the façade of Notre-Dame de Paris, which was to indirectly point to and legitimise the ancient power of the French monarchs. The demolition of the Romanesque abbey of Cluny III after the French Revolution is another example of political and social resentment transferred onto a work of art. It is significant that even the Romantic poet George Gordon Byron engraved his signature on a stone block in the Chillon Castle in Switzerland.

Masks as an element of architectural decoration, a figural detail, "populate" Romanesque and Gothic churches. It is worth noting that they had already been found in Greek and Roman capitals. ${ }^{75}$ Numerous typological analogies and examples of masks performing a similar function in Romanesque architecture can be indicated, for example, a Romanesque mask was set in a wall in Pliezhausen. In the case of the Inowrocław reliefs, their placement in the load-bearing wall was probably planned upon the moment of their creation, already during the building process. Thus, the masks stimulated the imagination of the recipients - initially, mainly the faithful churchgoers - from the turn of the $12^{\text {th }}$ and $13^{\text {th }}$ centuries. Despite all odds, the reliefs have survived until today in relatively good condition. Unfortunately, they have been affected by weather, causing natural erosion and weathering, which is not surprising as sculptures on church façades are often severely damaged by weather phenomena. Significantly, the placement of these anthropomorphic reliefs in the side wall is not one of the most natural or common if one compares it to the placement of various masks. They often form part of a capital, such as the late Romanesque crowned head projecting from its centre dating to the second quarter of the $13^{\text {th }}$ century and found in the Dominican church in Sandomierz. ${ }^{76}$ Many of them

${ }^{74}$ SIKORSKI, C.: Świadkowie 800-lecia: encyklopedia wiedzy o zabytkach Inowrocławia. Ed.: SIKORSKA, J. Inowrocław 2002, p. 302. The changing approach to medieval artworks, particularly sculptures, throughout history is discussed by BENGT, T.: Attitudes to the heritage, (Medieval wooden sculpture in Sweden 1). Stockholm 1964, passim.

${ }^{75}$ HEARN 1985 (see in note 35), p. 41 and footnote 2.

${ }^{76}$ ŚWIECHOWSKI 2006 (see in note 8), fig. on p. 210. 
also function as corbels, to mention expressive brick masks distinguished by exaggerated facial grimaces from the choir of the originally Cistercian church in Gdańsk-Oliwa, dated to around $1360 .{ }^{77}$ It is also worth recalling the late-Romanesque corbels with a similar structural arrangement and similar handling of artistic motifs as in the case of the Inowrockaw masks. The corbels are found in the tower chapel at the Braubach Castle and date to the second three decades of the $13^{\text {th }}$ century. This type also includes anthropo- and zoomorphic, yet extremely three-dimensional, masks constituting a part of the sculptural programme in the Königslutter Abbey, which was built from 1135 to the late $12^{\text {th }}$ century ${ }^{78}$. Their rich, diverse, narrative frieze required considerable skill and artistic imagination. Used as corbels, elements of the capital, masks are distinguished by a more vividly accentuated structural function. They also have an optical and real support under the architectural element of the church as well as an ornamental function, as they are part of the decorative frieze. This kind of architectural elements features Gothic leafy masks from whose mouth bunches of plant twigs sprout, sometimes also crowning the head, as in the case of the corbel in the Church of St. John in Gniezno from the mid- $14^{\text {th }}$ century, made in artificial stone. ${ }^{79}$ Moreover, they may share similar traits with mascarons with regard to features, shapes, and the juxtaposition of forming element, which have been deformed. Sometimes a small-sized anthropomorphic mask is dominated by a plant twig which occupies more space and covers the head which barely shows from among the twig. The twig is covered with a quasi-weave of parallel grooves and finished with palmettes. Dating to the late Romanesque and the

\footnotetext{
${ }^{77}$ HERRMANN, C. - VON WINTERFELD, D.: Zisterzienser. In: Mittelalterliche Architektur in Polen: romanische und gotische Baukunst zwischen Oder und Weichsel. Eds.: HERRMANN, C. VON WINTERFELD, D. Petersberg 2015, vol. 1, fig. 238 on p. 161; JURKOWLANIEC 1989 (see in note 28), pp. 97, 158, cat. no. 52.A.I.37, fig. 261.

${ }^{78}$ QUIRINI-POPLAWSKI 2006 (see in note 9), p. 142, fig. 98; KAISER, W.: Architektura romańska w Niemczech. In: Sztuka romańska. Ed.: TOMAN, R. Olsztyn 2000, pp. 63, 64, fig. on p. 63.
}

${ }^{79}$ KOWALSKI, J:: Grosspolen. In: HERRMANN - VON WIN- early Gothic periods, such floral ornamentation with anthropomorphic elements decorates the sandstone capital of the northern portal column in the Blessed Virgin Mary Church in Złotoryja. ${ }^{80}$

The semi-three-dimensional bas-reliefs shaped into masks also assume subtler and, at the same time, geometrised, and symmetrical forms as in the case of the keystone in the chapter house of the Cistercian church in Sulejów from the first half of the $13^{\text {th }}$ century. ${ }^{81}$ The keystone of the vault features four heads placed in a circle on the axis of two perpendicularly intersecting diameters; they were supplemented with an analogous composition twisted by 45 degrees in relation to the heads and filling the fields between them. The composition consisted of a pine cone and three pear-shaped elements covered with a single spiral groove. It should be added that the masks that comply with the law of the frame were also known in the late Gothic period. Examples include block-like, brick, almost compressed, fantastically leafy mascaron-cantilevers from the Dominican monastery and the town hall in Tangermünde. ${ }^{82}$

\section{Summary and conclusions, artistic genesis}

In a certain sense, the paper does not mention the creator of the Inowrocław bas-reliefs. This is because one will not obtain a satisfactory and unambiguous answer should one enquire who, where, how, when, why, and for whom made them or how they were perceived by particular groups of recipients at the time of their origin and in subsequent eras.

Popular experiments of thought in art history include the one mentioned by Hermann Bauer and consisting in recognising the late Gothic and

TERFELD 2015 (see in note 77), p. 293, fig. 512 on p. 294.

${ }^{80}$ JARZEWICZ 2014 (see in note 12), pp. 292-295, fig. on p. 293.

${ }^{81}$ Ibidem, fig. on p. 206.

${ }^{82}$ LISSOK, M.: Baugebundene Plastik der Spätgotik in der Altmark im letzten Drittel des 15. Jahrhunderts. In: Die mittelalterliche Plastik in der Mark Brandenburg: Protokollband des internationalen Kolloquiums von 2. bis 4. März 1989 in der Staatlichen Museen zи Berlin Bodemuseum. Eds.: LAMBACHER, L. - KAMMEL, F. M. Berlin 1990, pp. 66-72, figs. 35-38. 
particularly expressive retable from Isenheim made by Matthias Grünewald around 1512-1515 as a $19^{\text {th }}$-century piece. ${ }^{83}$ This experiment could be extended and applied to the above-mentioned works of Romanesque stonemasons' on whom no direct written sources that would originate before the $19^{\text {th }}$ century are available to researchers. Referring to the controversy surrounding the dating of a pre-modern painting, Max J. Friedländer - an expert on Early Netherlandish art - jokingly stated: "But we weren't there." ${ }^{84}$ With regard to Romanesque sculpture, Adam Bochnak expressed the opinion that: "In general, looking for influences everywhere can lead one astray." 85 However, even if research does not facilitate the dating of an artistic object that originated at a distant time, the academic apparatus of art history may help to make of the form and content of artworks understandable. Owing to analyses, one can define their changing place among the civilisational and academic achievements of subsequent periods and place them on the grid of relationships. Numerous analogies, the information about the construction of the church in Inowrocław or the placement of masks in walls confirm the date of their origin and their affiliation with the Romanesque style and period and a concrete place.

Significantly, due to their good fit with the load-bearing walls of the temple, the natural place of origin of the Inowrocław bas-reliefs was the lodge of the church dedicated to the Name of the Blessed Virgin Mary. Rainer Budde spotted only "gradational differences" between the figures in the portal jambs, capitals, and ordinary ashlars, ${ }^{86}$ while Jarosław Jarzewicz noticed similarities between the Inowrocław church and the churches from Western Pomerania and the Neumark in respect of the materials used and the horizontal projection of the

\footnotetext{
${ }^{83}$ BAUER, H.: Kunsthistorik. Eine kritische Einfübrung in das Studium der Kunstgeschichte. München 1989, p. 114.

${ }^{84}$ SAUERLÄNDER, W.: Alterssicherung, Ortssicherung und Individualsicherung. In: Kunstgeschichte: eine Einführung. Eds.: BELTING, H. et al., Berlin 2008, p. 132.

${ }^{85}$ BOCHNAK, A.: Historia squtuki średniowiecznej. Warszawa Kraków 1973, p. 122.
}

temples. This probably results from the copying of the same patterns from Saxony and the Margraviate of Brandenburg. The author mentioned the churches in Banie and Mętno Wielkie; yet, he paid special attention to St. Nicholas Church in Gdańsk dating to the early $13^{\text {th }}$ century and known from archaeological excavations. $^{87}$

It is worth mentioning the granite bas-reliefs in Schleswig-Holstein, dating to the late $12^{\text {th }}$ century, which are not distant in terms of time and even territory from the examples of architectural structure from Inowrocław. They were created during the construction of the Schleswig Cathedral and - despite the fact that they do not testify to good mastery of craftsmanship - they are distinguished by severity and had influence on subsequent sculptures. ${ }^{88}$ By contrast, the Inowrocław masks comprise of granite blocks which were modestly sculpted on one side only, but which still provoke many interpretations concerning their meaning and form and which intrigue viewers and researchers alike.

It should be remarked that it was the beginning of the $19^{\text {th }}$ century that became the turning point for both the Inowrocław reliefs and many works of medieval art in Poland. Since the turn of the $18^{\text {th }}$ and $19^{\text {th }}$ centuries, academic publications, antiquarianism, travel accounts, literary and sightseeing-related texts mentioning these artworks have been developing rapidly. A similar process can be traced while studying the example of the reception of the Gothic crucifix from St. Mary's Church in Gdańsk, elaborately described in fiction and academic literature as well as in the broadly defined literary output. ${ }^{89}$ Artworks, such as those discussed in this paper, are increasingly becoming the focus of interest for scholars, local communities as well as many recipients of art.

\section{(English translation by Magdalena Kopcrynniska)}

${ }^{86}$ BUDDE, R.: Deutsche romanische Skulptur 1050-1250. München 1979, p. 11.

${ }^{87}$ JARZEWICZ 2014 (see in note 12), p. 102.

${ }^{88}$ BUDDE 1979 (see in note 86), p. 17, figs. 145-150.

${ }^{89}$ WASZAK, P.: Krucyfikes ₹ Kaplicy Jedenastu Tysiecy Dziewic w Bazylice Mariackiej w Gdańsku. Jego znaczenie i recepcja. Toruń 2016, passim. 


\title{
Local and supra-regional significance of Romanesque sculpture and its place in art history - the example of bas-reliefs from a church in Inowrocław
}

\author{
Résumé
}

The last twenty years have seen intensified research into Romanesque architecture in Poland. This paper addresses the issue of Romanesque sculpture and presents it by means of describing several projecting reliefs preserved in the Romanesque, partially reconstructed, church dedicated to the Name of the Blessed Virgin Mary, a symbol of Inowrocław. The church is important for the local community. Many publications on Romanesque masks and representations have been published since the $19^{\text {th }}$ century, also recently. It is worth noticing that the opinions of researchers in the fields of history and art history are inconsistent. This text addresses the ensemble of Inowrocław sculptures analysed from a contemporary research and methodological perspective in respect of the history of medieval art as such an approach will allow for complementing the state of research. Artistic analogies, aesthetic sources, and the practice of ornamenting the Houses of God with stone masks have been presented and new interpretations of iconography, form, and meaning have been discussed. Formal issues concerning artistic geography, style, significance, meaning, and technique have been considered and compared. Besides, extensive reference has been made to the interpretation of the law of the frame. Another reference has been made with regard to the issue of the cultural meaning that was later provided to these popular artistic objects in Polish art history. A stylistic genesis and the closest formal analogies have been indicated. The starting point for the considerations presented herein was the notion of sites of memory.

Przemysław Waszak, PhD Department of the History of Art and Culture

Faculty of Fine Arts, Nicolaus Copernicus University in Torun ul. Sienkiewicza 30/32 87-100 Toruń e-mail:pwaszak@umk.pl 